\title{
MICROBIOLOGICAL QUALITY AND OTHER CHARACTERISTICS OF REFRIGERATED CHICKEN MEAT IN CONTACT WITH CELLULOSE ACETATE-BASED FILM INCORPORATED WITH ROSEMARY ESSENTIAL OIL
}

\section{Adriane Alexandre Machado de Meloํㅜ, Robson Maia Geraldine*1, Miriam Fontes Araujo Silveira1, Maria Célia Lopes Torres $^{1}$, Cíntia Silva Minafra e Rezende ${ }^{2}$, Thiago Henrique Fernandes ${ }^{1}$, Antonio Nonato de Oliveira²}

${ }^{1}$ Escola de Agronomia e Engenharia de Alimentos, Universidade Federal de Goiás, Goiânia, GO, Brasil; ${ }^{2}$ Escola de Veterinária, Universidade Federal de Goiás, Goiânia, GO, Brasil.

Submitted: December 14, 2010; Returned to authors for corrections: February 10, 2012; Approved: June 07, 2012.

\begin{abstract}
Antimicrobial active packaging delays or inhibits microorganism growth in packed products, and it can be used in a variety of food systems. The objective of the present research was to develop packaging incorporated with natural antimicrobial agents (active film). The effects of the active film on the spoilage, pathogenic microorganism counts, $\mathrm{pH}$ and color of the refrigerated chicken breast cuts were analyzed. Cellulose acetate-based active films incorporating two concentrations (20\% and 50\%, v/w) of rosemary (Rosmarinus officinalis L.) essential oil were manufactured and placed in contact with the chicken breast cuts for six days. An analysis of variance and mean comparison tests (Tukey's test, $\mathrm{p}<0.05$ ) were performed on the results. The films that contained $20 \%$ essential oil and were intercalated with chicken breast samples did not demonstrate significant effects on the control of psychrotrophic or total coliform microorganisms during the storage period; however, the films incorporated with 50\% essential oil demonstrated efficacy toward the control of coliforms during the storage of the samples ( 6 days, $\left.2 \pm 2{ }^{\circ} \mathrm{C}\right)$. The $\mathrm{pH}$ was related to the psychrotrophic microorganism count and was not influenced by the treatment. The color was not influenced by the time of storage or the treatment. The results demonstrate that active films incorporating $50 \%$ rosemary essential oil are effective at controlling certain microorganisms in chicken breast cuts.
\end{abstract}

Key words: active packaging, antimicrobial activity, cellulose acetate, Rosmarinus officinalis L., chicken.

\section{INTRODUCTION}

Microbiological changes are the most important modifications that occur in food because certain microorganisms are pathogenic and directly affect consumer health $(49,52)$, whereas others cause spoilage and diminish shelf life. Refrigerated chicken meat is a highly perishable product in which modifications are related to the growth of spoilage-inducing or pathogenic microorganisms $(34,39,40)$. Contamination can occur during the storage of the poultry or during slaughter due to human manipulation or through contact with the environment or contaminated water $(13,44,54,57)$.

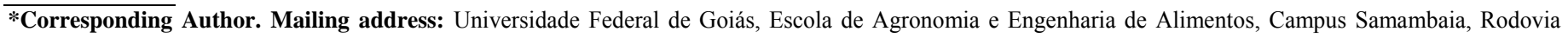
Goiânia-Nova Veneza, km 0, Zona Rural, CEP: 74690-900, Goiânia/Goiás.; Tel.: (62) 3521 1530.; E-mail: robson.agro.ufg@gmail.com 
The use of heat, cold, drying or chemical preservatives have the primary function of reducing the spoilage effects on meat (17); however, when considering fresh foods, such as poultry, most of the aforementioned methods should not be applied because they cause sensory changes that modify the product's characteristics (43). Food packaging also constitutes a preservation method as it creates a physical barrier between the product and the environment, thereby preventing contamination after packing and reducing biochemical and microbiological modifications $(1,38)$.

Many studies have been conducted to create "active packaging" methods that are not only able to protect but also to interact with the product $(31,55)$. This technology includes antimicrobial active packaging methods that are able to reduce the population growth, extend the lag phase and/or inactivate the microorganisms present in the food or in the package itself through contact $(4,43)$. There are several types of antimicrobial packaging methods, such as sachets or tablets with volatile antimicrobials, polymers that form films with inherent antimicrobial effects, polymers that are coated or incorporated with volatile or non-volatile antimicrobials (4, 17). With the exception of systems that use volatile agents, direct contact between the active packaging and the food is necessary (18). These packaging methods should not only have antimicrobial efficacy but they should also not negatively affect the sensory characteristics of the food (31).

Packaging materials can be manufactured from synthetic polymers, although the use of polymers will be more desirable when they do not cause a negative environmental impact due to disposal $(49,53)$. Antimicrobials used in packaging can be synthetic as well; however, there is a great interest in using natural practices to meet consumers' demands (19). Essential oils are natural compounds, the majority of which are Generally Recognized as Safe, and they can be used in food with no harm to the health of those who consume them (4). In Brazil, the use of vegetable oils in food packaging is allowed with no restrictions (10). The incorporation of clove, thyme, oregano and cinnamon essential oils in packaging to increase the shelf life of refrigerated meat has been previously described $(24,26,37)$.

Rosemary essential oil is a product of variable composition with oxygenated monoterpenes and hydrocarbons as primary components (29). The antimicrobial activity of rosemary oil has been demonstrated $(8,14,16,22)$; however, although there are reports of the incorporation of such compounds in films based on whey protein, the action of rosemary essential oil after the incorporated within packaging has not been thoroughly investigated (48).

Based on the aforementioned arguments, this objective of this study was to investigate the effect of films incorporated with rosemary essential oil on microbial growth, $\mathrm{pH}$ and the color of chicken breast cuts stored at $2 \pm 2^{\circ} \mathrm{C}$.

\section{MATERIALS AND METHODS}

\section{Materials}

Cellulose acetate was obtained from Rhodia (Freiburg, Germany), and acetone P.A. was obtained from Protec Produtos Científicos (Goiânia, GO, Brazil). Food-grade rosemary essential oil (Rosmarinus officinalis L.) was purchased from Petite Marie Química Nova (Itaquaquecetuba, SP, Brazil).

\section{Antimicrobial film preparation}

The films were prepared using the casting method described by Soares (51) with some modifications. The cast film-forming solution was prepared by adding cellulose acetate flakes to acetone $(10 \% \mathrm{w} / \mathrm{v}$; cellulose acetate/acetone), and the mixture was left to stand until its complete solubilization $(10 \mathrm{~h}$, $25 \pm 2^{\circ} \mathrm{C}$ ). Rosemary essential oil was added to the emulsion at final concentrations of $20 \%$ and $50 \%(\mathrm{v} / \mathrm{w}$; rosemary essential oil/cellulose acetate). Aliquots of the mixture were spread onto a glass plate (previously sanitized with alcohol at 70\%) followed by drying. Control films were prepared with no addition of the essential oil. Films of $25 \pm 5 \mu \mathrm{m}$ thickness were used (average of 10 measurements at random parts of the films 
using a micrometer Mitutoyo 0-25 mm), and all treatments were submitted to UV light for $2 \mathrm{~min}$. on each side prior to being placed in contact with the chicken breast cuts.

\section{Tray assembly}

The chicken breast cuts, weighing approximately $40 \mathrm{~g}$ and measuring 5-8 $\mathrm{mm}$ in thickness, were purchased at a local market inspected by the Municipal Inspecting Service (Goiânia, GO, Brazil). The inner surfaces of polystyrene trays were completely covered by an antimicrobial film, and five chicken breast cuts were placed one over the other in each tray and interspersed with antimicrobial films so that both sides of the cuts were in contact with the film. As a control, trays with no films were assembled. Each tray contained approximately $200 \mathrm{~g}$ of meat. Subsequently, the trays were wrapped with polyvinyl chloride (PVC) film $(15 \mu \mathrm{m})$ and stored under refrigeration $\left(2 \pm 2^{\circ} \mathrm{C}\right)$.

\section{Microbiological analysis}

Counts of psychrotrophs, total coliforms, thermotolerant coliforms and coagulase-positive Staphylococcus were performed at days 0,3 and 6 during storage. The assessment of Salmonella levels was conducted at day 0 and, for safety reasons, at day 3 . The repetition of the tests occurred at day 6 only in the event of the presence of microorganisms at day 0 or 3. The laboratory analyses followed a valid methodology for animal-origin products (9).

Chicken breast samples (25 g) from each treatment were aseptically weighed inside stomacher bags (Interlab, São Paulo, SP, Brazil), and $225 \mathrm{~mL}$ of $0.1 \%$ peptone water (Apijã, Goiânia, GO, Brazil) was poured into the bags and homogenized for $2 \mathrm{~min}$. Serial dilutions were prepared using $0.1 \%$ peptone water, and the inoculation was performed thereafter. To count the total number of psychrotrophs, $0.1 \mathrm{~mL}$ aliquots of the dilutions were inoculated onto a Petri dish surface containing plate count agar (Merck, São Paulo, SP, Brazil) and incubated at $8 \pm 1^{\circ} \mathrm{C}$ for 7 days. The total and thermotolerant coliform counts were performed using the agar- overlay method of inoculation for isolation with $1 \mathrm{~mL}$ aliquots from dilutions within the Petri dish using violet red bile agar (Merck, São Paulo, SP, Brazil) and incubation at $36 \pm 1{ }^{\circ} \mathrm{C}$ for $48 \mathrm{~h}$. Confirmation of the total coliforms was obtained using $2 \%$ brilliant green bile broth (Merck, São Paulo, SP, Brazil) at $36 \pm 1^{\circ} \mathrm{C}$ for 24 to $48 \mathrm{~h}$; for thermotolerant coliforms, EC broth (Merck, São Paulo, SP, Brazil) was used at $45 \pm 0.2^{\circ} \mathrm{C}$ for 24 to $48 \mathrm{~h}$.

An additional phase was used to quantify Staphylococcus and assess the occurrence of Salmonella. To count the coagulase-positive Staphylococcus, aliquots of $0.1 \mathrm{~mL}$ from the dilutions were inoculated onto a Petri dish surface containing Baird-Parker agar (Merck, São Paulo, SP, Brazil), egg yolk and $3.5 \%$ potassium tellurite (Merck, São Paulo, SP, Brazil). The occurrence of coagulase-positive Staphylococcus was confirmed was obtained by culturing typical and atypical colonies within tubes containing brain heart infusion broth (Merck, São Paulo, SP, Brazil) to perform a coagulase test using rabbit serum (Quimilab, Goiânia, GO, Brazil). To assess the occurrence of Salmonella, chicken breast samples (25 g) from each treatment were aseptically weighed inside stomacher bags, and $225 \mathrm{~mL}$ of buffered peptone water at $0.1 \%$ was poured into the bags and then homogenized for $2 \mathrm{~min}$. The bags were incubated for $24 \mathrm{~h}$ at $36 \pm 1^{\circ} \mathrm{C}$, and $0.1 \mathrm{~mL}$ aliquots were then incubated in Rappaport-Vassiliadis and Express (SX2-T) broths (Interlab, São Paulo, SP, Brazil) for $24 \mathrm{~h}$ at 41 $\pm 1^{\circ} \mathrm{C}$. After incubation, $2 \mathrm{~mL}$ of Express broth was heated in boiling water for $15 \mathrm{~min}$. to proceed with the analysis using the mini Vidas ${ }^{\circledR}$ IVD1202737 equipment (bioMérieux, Marcy l'Étoile, France).

The analyses were performed in two phases. In the first phase, trays with films incorporated with $20 \%(\mathrm{v} / \mathrm{w})$ of rosemary essential oil were assembled and analyzed; in addition, trays with films having no essential oil and the control (no film) were assembled. In the second phase, only trays with films incorporated with $50 \%(\mathrm{v} / \mathrm{w})$ of rosemary essential oil were assembled and analyzed in addition to the control. 


\section{pH measurement}

The $\mathrm{pH}$ was measured after the homogenization of $50 \mathrm{~g}$ of chicken breast samples with $20 \mathrm{~mL}$ of distilled water. The $\mathrm{pH}$ measurement was performed using a $\mathrm{pH}$ meter combined with an electrode for $\mathrm{pH}$ (Logen Scientific - LS 300, 5204). The measurements were done in triplicate.

\section{Color analysis}

The analysis of the color of the chicken breast samples was performed only during the second phase of the experiment to identify whether the films would interfere with this attribute. The analysis was performed using a ColorQUEST II colorimeter (Hunterlab, 6553) with Universal Software Version 3.6 operating on a CIE $\mathrm{L}^{*} \mathrm{a}{ }^{*} \mathrm{~b}^{*}$ standard. The system was operated using Standard Illuminant D65 with a $10^{\circ}$ angle, and measurements were made directly on the samples (three measurements at random parts of each chicken breast cut). The colorimeter was calibrated prior to the evaluation with the parameters black, white and gray with white selected for use as the parameter $\left(L^{*}=94.18, a^{*}=-0.93, b^{*}\right.$ $=0.48)$.

\section{Statistical analyses}

A completely randomized design was selected. The experiment was conducted in three repetitions. The results were submitted to an ANOVA with an F test, and when relevant, a Tukey's test was applied at a 5\% probability. The Statistical Analysis System 6.0 program was used for the calculations (47).

\section{RESULTS AND DISCUSSION}

\section{Antimicrobial activity of films in contact with chicken meat}

In a previous study, the antimicrobial activity of films incorporating $0,10 \%, 20 \%, 30 \%, 40 \%$ and $50 \%(\mathrm{v} / \mathrm{w})$ of rosemary essential oil was evaluated in vitro. The procedure was based on the disk diffusion in agar method of the National Committee for Clinical Laboratory Standards, which is recommended by the National Health Surveillance Agency (3) for testing the in vitro susceptibility of aerobic bacteria to antimicrobial agents. In the in vitro system, between $10^{4}$ and $10^{5} \mathrm{CFU}^{-1}$ of mesophilic microorganisms obtained from the chicken meat were used (data submitted for publication). The results obtained from this previous work guided the use of essential oils in the present study.

The results of the counts of psychrotrophs, total coliforms, thermotolerant coliforms, coagulase-positive Staphylococcus and occurrence of Salmonella in the chicken breast samples treated with films without the incorporation of rosemary essential oil $(0 \%$ film) or films incorporated with $20 \%$ (v/w) rosemary essential oil (20\% film) and controls are presented in Table 1.

Table 1. Microbial activity $\left(\log\right.$ CFU.g $\left.\mathrm{g}^{-1}\right)$ in chicken meat submitted to treatments during storage at $2 \pm 2^{\circ} \mathrm{C}$.

\begin{tabular}{|c|c|c|c|c|}
\hline \multirow[t]{2}{*}{ Microorganism } & \multirow[t]{2}{*}{ Treatment } & \multicolumn{3}{|c|}{ Day ${ }^{1}$} \\
\hline & & 0 & 3 & 6 \\
\hline \multirow[t]{3}{*}{ Psychrotrophic } & Control & $5.45^{\mathrm{Aa}}$ & $6.61^{\mathrm{Ab}}$ & $7.57^{\mathrm{Ac}}$ \\
\hline & $0 \%$ film & $5.45^{\mathrm{Aa}}$ & $6.59^{\mathrm{Ab}}$ & $7.52^{\mathrm{Ac}}$ \\
\hline & $20 \%$ film & $5.45^{\mathrm{Aa}}$ & $6.77^{\mathrm{Ab}}$ & $7.71^{\mathrm{Ac}}$ \\
\hline \multirow[t]{2}{*}{ Total coliforms } & Control & $4.40^{\mathrm{Aa}}$ & $3.99^{\mathrm{Aa}}$ & $3.58^{\mathrm{Aa}}$ \\
\hline & $20 \%$ film & $4.40^{\mathrm{Aa}}$ & $4.42^{\mathrm{Aa}}$ & $3.36^{\mathrm{Aa}}$ \\
\hline \multirow[t]{3}{*}{ Thermotolerant coliforms } & Control & $<1$ & $<1$ & $<1$ \\
\hline & $0 \%$ film & $<1$ & $<1$ & $<1$ \\
\hline & $20 \%$ film & $<1$ & $<1$ & $<1$ \\
\hline Salmonella & $20 \%$ film & absence & absence & - \\
\hline Positive coagulase & Control & $<1$ & $<1$ & $<1$ \\
\hline \multirow[t]{2}{*}{ Staphylococcus } & $0 \%$ film & $<1$ & $<1$ & $<1$ \\
\hline & $20 \%$ film & $<1$ & $<1$ & $<1$ \\
\hline
\end{tabular}

${ }^{1}$ Figures correspond to the average of three replicates. Capital letters represent the treatment, and small letters indicate the time. Averages followed by the same capital letter in the column and followed by a small letter in the row are not significantly different $(\mathrm{p}>0.05)$. 
The initial count of psychrotrophic microorganisms in the samples was $2.810^{5} \mathrm{CFU}^{-1} \mathrm{~g}^{-1}$. The microbial agents assessed here are the primary causes of refrigerated meat spoilage $(2$, $11,34)$, and although Brazilian legislation has not established limits for psychrotrophic counts in chicken meat, the value presented in this manuscript is considered high according to the literature; the first signs of spoilage, such as inappropriate odors, are noticeable at counts greater than $10^{7} \mathrm{CFU}^{-1}{ }^{-1}(20,23$, 30). Therefore, after the sixth day of storage, the chicken meat would be inadequate for consumption.

There was no significant difference in the growth of microorganisms between the control samples and the $0 \%$ film, thereby indicating that the cellulose acetate-based films without essential oil had no influence upon the growth of the analyzed microorganisms. Films incorporated with $20 \%$ of the essential oil were not effective at diminishing or avoiding psychrotrophic growth, thus indicating that the film at this oil concentration does not significantly contribute to an extended shelf life. The total coliform count did not significantly vary based on the days of storage $(p>0.05)$. The absence of Salmonella as well as thermotolerant coliform and coagulasepositive Staphylococcus counts of less than $10 \mathrm{CFU}^{-1}$ on the chicken breast samples indicated that the raw material used in the tests was of high quality; thus, it was not possible to assess the efficacy of the films upon these organisms.

The non-efficacy of the active film with $20 \%$ of the essential oil could be related to the short contact time with the meat. We can infer that to obtain a positive response, a longer contact time between the film and the system may be necessary (35). The $\mathrm{pH}$ of a product can also have an influence on the activities of active agents because the $\mathrm{pH}$ can modify the extent of ionization (dissociation/ionization) of certain compounds and consequently affect their activity (28). Gutierrez et al. (27) described studies using essential oils of oregano and thyme in which a $\mathrm{pH}$ of 5 was favorable for the activities of the oils. According to the authors, the low $\mathrm{pH}$ increased the oil hydrophobicity, thereby facilitating their passage through the membranes of bacterial cells. It is worth considering that the average $\mathrm{pH}$ in refrigerated chicken breast meat was greater than 6 on days 0,3 and 6 , and therefore, the $\mathrm{pH}$ was not in the optimal range described by Gutierrez et al.

Perhaps the most important consideration is the food system itself, which is deeply connected to the concentration of the essential oil in the films. Devlieghere et al. (19) reported the possibility of interactions between antimicrobial compounds and food components, such as proteins and fat; such interactions may influence the efficacy of the antimicrobial compounds. Due to the possible interactions between compounds and ingredients, according to Moreira et al. (35), there is no direct contact between the agents and microorganisms in food systems. Fat and/or protein molecules act as physical barriers to the antimicrobial agents, which protects the microorganisms from the antimicrobial activity (12). In a study of hotdogs, Singh et al. (50) demonstrated a significant reduction in the antimicrobial activity of thyme and clove essential oils following changes in the fat level of the hotdogs from zero to $9 \%$.

Studies have demonstrated that the control of microorganisms is improved when a greater concentration of antimicrobial agents is incorporated into the packaging (42, 58 ), and the quantity of such microorganisms in the product can determine the activity of certain active components (15). Ponce et al. (41) reported that active components have a specific concentration of maximum inhibition, and when the microorganism count is greater than this ability, growth control is not effective. The results of microbial growth during the second phase of the experiment are presented in Table 2. 
Table 2. Microbial activity $\left(\log \mathrm{CFU} \cdot \mathrm{g}^{-1}\right)$ in chicken meat submitted to treatments during storage at $2 \pm 2^{\circ} \mathrm{C}$.

\begin{tabular}{|c|c|c|c|c|}
\hline \multirow[t]{2}{*}{ Microorganism } & \multirow[t]{2}{*}{ Treatment } & \multicolumn{3}{|c|}{ Day ${ }^{1}$} \\
\hline & & $\mathbf{0}$ & 3 & 6 \\
\hline \multirow[t]{2}{*}{ Psychrotrophic } & Control & $<1^{\mathrm{Aa}}$ & $5.21^{\mathrm{Ab}}$ & $6.57^{\mathrm{Ab}}$ \\
\hline & $50 \%$ film & $<1^{\mathrm{Aa}}$ & $4.49^{\mathrm{Ab}}$ & $6.86^{\mathrm{Ab}}$ \\
\hline \multirow[t]{2}{*}{ Total coliforms } & Control & $<1^{\mathrm{Aa}}$ & $3.84^{\mathrm{Ab}}$ & $4.56^{\mathrm{Ab}}$ \\
\hline & $50 \%$ film & $<1^{\mathrm{Aa}}$ & $2.62^{\mathrm{Aa}}$ & $2.39^{\mathrm{Ba}}$ \\
\hline \multirow[t]{2}{*}{ Thermotolerant coliforms } & Control & $<1$ & $<1$ & $<1$ \\
\hline & $50 \%$ film & $<1$ & $<1$ & $<1$ \\
\hline \multirow[t]{2}{*}{ Salmonella } & Control & absence & absence & - \\
\hline & $50 \%$ film & absence & absence & - \\
\hline Positive coagulase & Control & $<1$ & $<1$ & $<1$ \\
\hline Staphylococcus & $50 \%$ film & $<1$ & $<1$ & $<1$ \\
\hline
\end{tabular}

Although the initial psychrotrophic count was less than 10 CFU.g ${ }^{-1}$, the count was approximately $10^{7}$ CFU.g ${ }^{-1}$ on day 6. The observed microbial growth is related to the favorable temperature for these microorganisms (2), high level of nutrients, high water activity and the $\mathrm{pH}$, which make poultry meat susceptible to spoiling (21).

Even considering the low initial microbial count, there was no significant difference $(\mathrm{p}>0.05)$ between the control and treatments on different days with respect to the psychrotrophic growth; however, the total coliform growth was greatly reduced on day $6(\mathrm{p} \leq 0.05)$ for the $50 \%$ films relative to the control, which represents an average difference of 2 logarithmic growth cycles. The results indicate that there was no reduction in the total coliform count, although the growth of these microorganisms was controlled during storage. The control of microorganism growth by antimicrobial agents can occur through a reduction in the growth rate, an increase in the lag phase or through direct inactivation by contact between the active agents and microorganisms (43). Therefore, the treatment may have presented at least one of these roles. According to the results for the films with 50\% rosemary essential oil, this packaging method is effective against certain total coliforms and is likely effective against other microorganisms.
Studies conducted by Santiago-Silva et al. (46) indicate that films made with cellulose acetate incorporating $25 \%$ or $50 \%$ of pediocin $(\mathrm{w} / \mathrm{w})$ were effective in the control of Listeria innocua within sliced ham samples stored at $12 \pm 1^{\circ} \mathrm{C}$, and the reduction was proportional to the concentration of pediocin within the films (2 logarithmic cycles in samples treated with $50 \%$ films and less than 1 cycle in samples treated with $25 \%$ films). However, the treatments were not as effective in the control of Salmonella sp. Zinoviadou et al. (58) also reported a significant reduction in the growth of the assessed microorganisms as the concentration of oregano essential oil was increased from $0.5 \%$ to $1.5 \%$ in whey protein isolate films. In addition, it was demonstrated that lactic acid bacteria were more sensitive to the active components of oils than Pseudomonas. Both studies demonstrate that the efficacy of antimicrobial films is influenced by the susceptibility of each microorganism to the active agents in addition to other factors.

\section{pH value}

In the first phase of the experiment, no statistical variance $(\mathrm{p}>0.05)$ in the $\mathrm{pH}$ of the samples was detected. The initial average $\mathrm{pH}$ was 6.08 , and the maximum value of 6.13 was reached on day 6 . Foods that are stored under aerobiosis and rich in proteins and free amino acids, such as chicken meat, 
commonly present a $\mathrm{pH}$ increase as the numbers of microorganisms that cause spoilage rises $(5,32,36)$; i.e., their proteolytic activity results in the production of basic compounds (56), thereby causing a slight $\mathrm{pH}$ increase. In the second phase, there was no significant $\mathrm{pH}$ variance between the days and treatments; the values were 6.09 on day 0 and 6.04 on day 6.

\section{Color analysis}

The color analysis of the control samples and the $50 \%$ film demonstrated no significant variance $(\mathrm{p}>0.05)$ related to the $\mathrm{L}^{*} \mathrm{a} * \mathrm{~b} *$ parameters between the days and treatments. Probably, neither lipid oxidation nor relevant metmyoglobin formation were evident during this period. It has been reported that rosemary compounds possess antioxidant action $(6,25,33$, 45) and are able to contribute to the maintenance of meat color if the formation of metmyoglobin and lipid oxidation are avoided. However, such results were not observed in the present study.

The aforementioned results have been taken into account, as the primary objective of antimicrobial packaging is to control microbial growth; the fact they have not caused negative variations on meat color is highly positive (7).

\section{CONCLUSION}

The use of cellulose acetate-based active films incorporating $20 \%$ rosemary essential oil did not significantly reduced the growth of psychrotrophic microorganisms and total coliforms within the refrigerated chicken meat; however, films incorporating $50 \%$ rosemary essential oil were effective in controlling total coliforms. The slight variation in the $\mathrm{pH}$ value of the chicken meat was related to the growth of psychrotrophs, and there was no significant variance between the treatments. The color of the meat was not influenced by the use of films incorporating 50\% rosemary essential oil, and the color did not significantly vary during storage.

\section{ACKNOWLEDGEMENTS}

The authors are grateful to Capes for financial support, Federal University of Goiás (UFG) for the scholarship granted to Adriane Alexandre Machado de Melo and the Food Research Center (CPA) (Veterinary School - UFG) for allowing the performance of laboratory tests.

\section{REFERENCES}

1. Álvarez, M.F. (2000). Revisión: Envasado activo de los alimentos. Food Sci. Technol. Int., 6 (2), 97-108.

2. Álvarez-Astorga, M.; Capita, P.; Alonso-Calleja, C.; Moreno, B.; GarcíaFernández, M.C. (2002). Microbiological quality of retail chicken byproducts in Spain. Meat Sci., 62 (1), 45-50.

3. Anvisa-Agência Nacional de Vigilância Sanitária. Normas de Desempenho para Testes de Sensibilidade Antimicrobiana: $15^{\circ}$ Suplemento Informativo. v. 25, n. 2, 2009.

4. Appendini, P.; Hotchkiss, J.H. (2002). Review of antimicrobial food packaging. Innov. Food Sci. Emerg. Technol., 3 (2), 113-126.

5. Balamatsia, C.C.; Paleologos, E.K.; Kontominas, M.G.; Savvaidis, I.N. (2006). Correlation between microbial flora, sensory changes and biogenic amines formation in fresh chicken meat stored aerobically or under modified atmosphere packaging at $4^{\circ} \mathrm{C}$ : possible role of biogenic amines as spoilage indicators. Antonie van Leeuwenhoek, 89 (1), 9-17.

6. Bentayeb, K.; Rubio, C.; Batle, R.; Nerín, C. (2007). Direct determination of carnosic acid in a new active packaging based on natural extract of rosemary. Anal. Bioanal. Chem., 389 (6), 1989-1996.

7. Botrel, D.A.; Soares, N.F.F.; Geraldine, R.M.; Pereira, R.M.; Fontes, E.A.F. (2007). Qualidade de alho (Allium sativum) minimamente processado envolvido com revestimento comestível antimicrobiano. Cienc. Tecnol. Aliment., 27 (1), 32-38.

8. Bozin, B.; Mimica-Dukic, N.; Samojlik, I.; Jovin, E. (2007). Antimicrobial and antioxidant properties of rosemary and sage (Rosmarinus officinalis L. and Salvia officinalis L., Lamiaceae) essential oils. J. Agric. Food Chem., 55 (19), 7879-7885.

9. Brasil-Instrução Normativa $\mathrm{n}^{\circ} 62$, de 26 de agosto de 2003. Oficializa os Métodos Analíticos Oficiais para Análises Microbiológicas para Controle de Produtos de Origem Animal e Água. Ministério da Agricultura, Pecuária e Abastecimento, Brasília, DF, 2003.

10. Brasil-Resolução RDC $\mathrm{n}^{\circ} 17$, de 17 de março de 2008. Dispõe sobre Regulamento Técnico sobre Lista Positiva de Aditivos para Materiais Plásticos destinados à Elaboração de Embalagens e Equipamentos em Contato com Alimentos. Agência Nacional de Vigilância Sanitária, Brasília, DF, 2008. 
11. Bunková, L.; Bunka, F.; Klcovská, P.; Mrkvicka, V.; Dolezalová, M.; Krácmar, S. (2010). Formation of biogenic amines by Gram-negative bacteria isolated from poultry skin. Food Chem., 121 (1), 203-206.

12. Burt, S. (2004). Essential oils: their antibacterial properties and potential applications in foods - a review. Int. J. Food Microbiol., 94 (3), 223253.

13. Carvalho, A.C.F.B.; Cortez, A.L.L. (2005). Salmonella spp. em carcaças, carne mecanicamente separada, linguiças e cortes comerciais de frango. Cienc. Rural, 35 (6), 1465-1468.

14. Celiktas, O.Y.; Kocabas, E.E.H.; Bedir, E.; Sukan, F.V.; Ozek, T.; Baser, K.H.C. (2007). Antimicrobial activities of methanol extracts and essential oils of Rosmarinus officinalis, depending on location and seasonal variations. Food Chem., 100 (2), 553-559.

15. Ceylan, E.; Fung, D.Y.C. (2004). Antimicrobial activity of spices. J. Rapid Methods Autom. Microbiol., 12 (1), 1-55.

16. Cimanga, K.; Kambu, K.; Tona, L.; Apers, S.; Debruyne, T.; Herpnans, N.; Totté, J.; Pieters, L; Vlietinck, A.J. (2002). Correlation between chemical composition and antibacterial activity of essential oils of some aromatic medicinal plant growing in the democratic republic of Congo. J. Ethnopharmacol., 79 (2), 213-220.

17. Coma, V. (2008). Bioactive packaging technologies for extended shelf life of meat-based products. Meat Sci., 78 (1-2), 90-103.

18. Cooksey, K. (2001). Antimicrobial food packaging materials. Additives for Polymers, 2001 (8), 6-10.

19. Devlieghere, F.; Vermeiren, L.; Debevere, J. (2004). New preservation technologies: Possibilities and limitations. Int. Dairy J., 14 (4), 273-285.

20. Dickens, J.A.; Ingram, K.D.; Hinton Jr, A. (2004). Effects of Applying $\mathrm{Safe}_{2} \mathrm{O}$ Poultry Wash to Broiler Wings on Shelf Life, Listeria monocytogenes, Pseudomonads, Staphylococcus species, and psychrotrophic bacteria levels after three, seven, and ten days of storage. Poult. Sci., 83 (6), 1047-1050.

21. Dillon, V.M. (1998). Yeasts and moulds associated with meat and meat products. In: Daves, A., Board, R. (eds). The Microbiology of Meat and Poultry. Blackie Academic \& Professional, London, UK, p. 85-117.

22. Dorman, H.J.D.; Deans, S.G. (2000). Antimicrobial agents from plants antibacterial activity of plant volatile oils. J. Appl. Bacteriol., 88 (2), 308-316

23. Economou, T.; Pournis, N.; Ntzimani, A.; Savvaidis, I.N. (2009). NisinEDTA treatments and modified atmosphere packaging to increase fresh chicken meat shelf-life. Food Chem., 114 (4), 1470-1476.

24. Emiroğlu, Z.K.; Yemiş, G.P.; Coşkun, B.K.; Candoğan, K. (2010). Antimicrobial activity of soy edible films incorporated with thyme and oregano essential oils on fresh ground beef patties. Meat Sci., 86 (2), 283-288.

25. Formanek, Z.; Kerry, J.P.; Higgins, F.M.; Buckley, D.J.; Morrissey, P.A.; Farkas, J. (2001). Addition of synthetic and natural antioxidants to $\alpha$-Tocopheryl acetate supplemented beef patties: effects of antioxidants and packaging on lipid oxidation. Meat Sci., 58(4), 337-341.

26. Gómez-Estaca, J.; López de Lacey, A.; López-Caballero, M.E.; GómezGuillén, M.C.; Montero, P. (2010). Biodegradable gelatin-chitosan films incorporated with essential oils as antimicrobial agents for fish preservation. Food Microbiol., 27 (7), 889-896.

27. Gutierrez, J.; Barry-Ryan, C.; Bourke, P. (2008). The antimicrobial efficacy of plant essential oil combinations and interactions with food ingredients. Int. J. Food Microbiol., 124 (1), 91-97.

28. Han, J.H. (2000). Antimicrobial Food Packaging. Food Technol., 54 (3), $56-65$.

29. Hussain, A.I. (2009). Characterization and biological activities of essential oils of some species of Lamiaceae. Faisalabad, Pakistan, 257p. (Ph.D. Thesis. Faculty of Sciences. University of Agriculture).

30. Jay, J.M.; Loessner, M.J.; Golden, D.A. (2005). Modern food microbiology. Springer Science, New York.

31. Kerry, J.P.; O’Grady, M.N.; Hogan, S.A. (2006). Past, current and potential utilisation of active and intelligent packaging systems for meat and muscle-based products: a review. Meat Sci., 74 (1), 113-130.

32. Krizek, M.; Vácha, F.; Vorlová, L.; Lukásová, J.; Cupákova, S. (2004). Biogenic amines in vacuum-packed and non-vacuum-packed flesh of carp (Cyprinus carpio) stored at different temperatures. Food Chem., 88 (2), 185-191.

33. Mariutti, L.R.B.; Barreto, G.P.M.; Bragagnolo, N.; Mercadante, A.Z. (2008). Free radical scavenging activity of ethanolic extracts from herbs and spices commercialized in Brazil. Braz. Arch. Biol. Technol., 51 (6), 225-1232.

34. Mead, G.C. (2004). Microbiological quality of poultry meat: a review. Rev. Bras. Cienc. Avic., 6 (3), 135-142.

35. Moreira, M.R.; Ponce, A.G.; Del Valle, C.E.; Roura, S.I. (2007). Effects of clove and tea tree oils on Escherichia coli o157:h7 in blanched spinach and minced cooked beef. J. Food Process. Preserv., 31 (4), 379391.

36. Ntzimani, A.G.; Paleologos, E.K.; Savvaidis, I.N.; Kontominas, M.G. (2008). Formation of biogenic amines and relation to microbial flora and sensory changes in smoked turkey breast fillets stored under various packaging conditions at $4^{\circ}$ C. Food Microbiol., 25 (3), 509-517.

37. Ojagh, S.M.; Rezaei, M.; Razavi, S.H.; Hosseini, S.M.H. (2010). Development and evaluation of a novel biodegradable film made from chitosan and cinnamon essential oil with low affinity toward water. Food Chem., 122 (1), 161-166.

38. Oliveira, L.M.; Oliveira, P.A.P.L.V. (2004). Revisão: principais agentes antimicrobianos utilizados em embalagens plásticas. Braz. J. Food Technol., 7 (2), 161-165.

39. Pelisser, M.R.; Mendes, S.D.C.; Sutherland, A.D.; Batista, C.R.V. (2001). Detection of Listeria species in refrigerated chicken carcasses using clearview $^{\mathrm{TM}}$ and a modified conventional culture method. Braz. J. Microbiol., 32 (2), 113-116. 
40. Pepe, O.; Blaiotta, G.; Bucci, F.; Anastasio, M.; Aponte, M.; Villani, F. (2006). Staphylococcus aureus and staphylococcal enterotoxin A in breaded chicken products: detection and behavior during the cooking process. Appl. Environ. Microbiol., 72 (11), 7057-7062.

41. Ponce, A.G.; Roura, S.I.; Del Valle, C.E.; Moreira, M.R. (2008). Antimicrobial and antioxidant activities of edible coatings enriched with natural plant extracts: in vitro and in vivo studies. Postharvest biol. technol., 49 (2), 294-300.

42. Pranoto, Y.; Rakshit, S. K.; Salokhe, V.M. (2005). Enhancing antimicrobial activity of chitosan films by incorporating garlic oil, potassium sorbate and nisin. Lebensm. Wiss. Technol., 38 (8), 859-865.

43. Quintavalla, S.; Vicini, L. (2002). Antimicrobial food packaging in meat industry. Meat Sci., 62 (3), 373-380.

44. Rodrigues, A.C.A.; Pinto, P.S.A.; Vanetti, M.C.D.; Bevilacqua, P.D.; Pinto, M.S.; Nero, L.A. (2008). Análise e monitoramento de pontos críticos no abate de frangos utilizando indicadores microbiológicos. Cienc. Rural, 38 (7), 1948-1953.

45. Sacchetti, G.; Maietti, S.; Muzzoli, M.; Scaglianti, M.; Manfredini, S.; Radice, M.; Bruni, R. (2005). Comparative evaluation of 11 essential oils of different origin as functional antioxidants, antiradicals and antimicrobials in foods. Food Chem., 91 (4), 621-632.

46. Santiago-Silva, P.; Soares, N.F.F.; Nóbrega, J.E.; Júnior, M.A.W.; Barbosa, B.F.; Volp, A.C.P.; Zerdas, E.R.M.A.; Würlitzer, N.J. (2009). Antimicrobial efficiency of film incorporated with pediocin $\left(\right.$ ALTA $^{\circledR}$ 2351) on preservation of sliced ham. Food Control, 20 (1), 85-89.

47. Statistical Analysis System Institute (1996). Sas/Qc Software: Usage and Reference (version 6), second ed. Cary (1CD-ROM).

48. Seydim, A.C.; Sarikus, G. (2006). Antimicrobial activity of whey protein based edible films incorporated with oregano, rosemary and garlic essential oils. Food Res. Int., 39 (5), 639-644.
49. Silveira, M.F.A. (2005). Filme antimicrobiano incorporado com ácido sórbico na conservação de massa de pastel. Viçosa, Brasil, 64p. (D.Sc. Thesis. Departamento de Tecnologia de Alimentos. UFV).

50. Singh, A.; Singh, R.K.; Bhunia, A.K.; Singh, N. (2003). Efficacyof plant essential oils as antimicrobial agents against Listeria monocytogenes in hotdogs. Lebensm. Wiss. Technol., 36 (8), 787-794.

51. Soares, N.F.F. (1998). Bitterness reduction in citrus juice through naringinase immobilized into polymer film. New York, USA, 130p. (Ph. D. Dissertation. Comell University).

52. Tajkarimi, M.M.; Ibrahim, S.A.; Cliver, D.O. (2010). Antimicrobial herb and spice compounds in food. Food Control, 21 (9), 1199-1218.

53. Tharanathan, R. N. (2003). Biodegradable films and composite coatings: past, present and future. Trends Food Sci. Technol., 14 (3), 71-78.

54. Tsola, E.; Drosinos, E.H.; Zoiopoulos, P. (2008). Impact of poultry slaughter house modernisation and updating of food safety management systems on the microbiological quality and safety of products. Food Control, 19 (4), 423-431.

55. Vermeiren, L.; Devlieghere, F.; Van Beest, M.; Kruijf, N.; Debevere, J. (1999). Developments in the active packaging of foods. Trends Food Sci. Technol., 10 (3), 77-86.

56. Vinci, G.; Antonelli, M.L. (2002). Biogenic amines: quality index of freshness in red and white meat. Food Control, 13 (8), 519-524.

57. Von Rückert, D.A.S.; Pinto, P.S.A.; Santos, B.M.; Moreira, M.A.S.; Rodrigues, A.C.A. (2009). Pontos críticos de controle de Salmonella spp. no abate de frangos. Arq. Bras. Med. Vet. Zootec., 61 (2), 326-330.

58. Zinoviadou, K.G.; Koutsoumanis, K.P.; Biliaderis, C.G. (2009). Physicochemical properties of whey protein isolate films containing oregano oil and their antimicrobial action against spoilage flora of fresh beef. Meat Sci., 82 (3), 338-345. 